\title{
Electrolyte balance and crude protein requirement of laying Japanese quail
}

\author{
Níveis de balanço eletrolítico e proteína bruta para \\ codornas japonesas na fase de postura
}

\author{
Danilo Vargas Gonçalves Vieira ${ }^{1}$; Talita Pinheiro Bonaparte ${ }^{2 *}$; \\ José Geraldo de Vargas Júnior ${ }^{3}$; Walter Amaral Barboza ${ }^{3}$; Rita da Trindade Ribeiro \\ Nobre Soares ${ }^{4}$; Silvana Marques Pastore ${ }^{5}$; Flávio Medeiros Vieites ${ }^{6}$
}

\begin{abstract}
The objective of this study was to evaluate the effects of two levels of crude protein and five levels of electrolyte balance on the performance and egg-quality of laying Japanese quail. Six hundred 45-dayoldquails were distributed in a randomized-block design with a $5 \times 2$ factorial arrangement comprising ten treatments, five replicates, and 12 birds per experimental unit. The electrolyte balance levels were $50,125,200,275$, and $350 \mathrm{mEq} \mathrm{kg}{ }^{-1}$ of diet, and crude protein (CP) levels were 210 and $240 \mathrm{~g} \mathrm{~kg}^{-1}$. The performance and egg-quality variables assessed were: feed intake, feed conversion, egg-laying percentage, egg weight and mass, and albumin, yolk and shell weight. There were no interactions among the studied factors. The electrolyte balance and crude protein levels did not significantly affect the performance variables. However, increased shell weight of eggs stored for seven days was observed at an electrolyte balance level of $200 \mathrm{mEq} \mathrm{kg}{ }^{-1}$. With regard to the CP levels, increased egg weight was observed at 28 days at a level of $210 \mathrm{~g} \mathrm{~kg}^{-1}$, whereas increased albumin weight was observed at 35 days of storage at a level of $240 \mathrm{~g} \mathrm{~kg}^{-1}$. A tendency toward an increase in egg albumin weight during the storage period of 14 days was observed. Based on the findings of this study, it is recommended that the diet for Japanese quails in the laying phase be formulated with an electrolyte balance of $50 \mathrm{mEq} \mathrm{kg}{ }^{-1}$ and $240 \mathrm{~g} \mathrm{~kg}^{-1}$ of crude protein This diet did not have a negative effect on productive performance, and by increasing the weight of egg albumin, eggs can be stored for a longer duration, thus demonstrating an alternative method to increase the shelf life of eggs.
\end{abstract}

Key words: Chlorine, egg quality, performance, potassium, sodium

\section{Resumo}

Com o objetivo de avaliar os efeitos de cinco níveis de balanço eletrolítico e dois níveis de proteína bruta sobre o desempenho e a qualidade de ovos de codornas japonesas na fase de produção, 600 codornas com 45 dias de idade foram distribuídas em delineamento em bloco casualizado, esquema fatorial (5x2), dez tratamentos, cinco repetições e 12 aves por unidade experimental. Os níveis de balanço eletrolítico avaliados foram $50 ; 125 ; 200 ; 275$ e $350 \mathrm{mEq} \mathrm{kg}^{-1}$ de ração e os níveis de proteína bruta (PB) foram 210

1 Prof. Adjunto, Universidade Federal do Tocantins, UFT, Araguaína, TO, Brasil. E-mail: danilovargaszoo@hotmail.com

2 Discente de Pós-Doutorado PNPD, Programa de Pós-Graduação Stricto sensu em Ciências Veterinárias, Universidade Federal do Espírito Santo, UFES, Alegre, ES, Brasil. E-mail: talitabonaparte@gmail.com

3 Profs. Associado, UFES, Alegre, ES, Brasil. E-mail: josegeraldovj@hotmail.com; barbozawa@hotmail.com

4 Prof Titular, Universidade Estadual do Norte Fluminense, UENF, Campos dos Goytacazes, RJ, Brasil. E-mail: rnobre@uenf.br

5 Discente de Doutorado PNPD no Programa de Pós-Graduação Stricto sensu em Zootecnia, Universidade Federal de Viçosa, UFV, Viçosa, MG, Brasil. E-mail: silvanazoo@hotmail.com

6 Prof. Associado, Universidade Federal de Juiz de Fora, UFJF, Juiz de Fora, MG, Brasil. E-mail: fmvieites@yahoo.com.br

* Author for correspondence 
e $240 \mathrm{~g} \mathrm{~kg}^{-1}$. As variáveis de desempenho e qualidade dos ovos analisadas foram: consumos de ração, conversão alimentar, porcentagem de postura, peso e massa de ovos, peso de albúmen, gema e casca. Os dados de peso do ovo e peso da casca foram registrados em diferentes tempos de armazenamento dos ovos e analisados dentro de cada tempo. Observou-se que não houve efeito da interação entre os fatores estudados. Os níveis do balanço eletrolítico e proteína bruta não influenciaram significativamente as variáveis de desempenho. Entretanto o nível de $200 \mathrm{mEq} \mathrm{kg}^{-1}$ melhorou o peso da casca de ovos armazenados por sete dias. Com relação aos níveis de $\mathrm{PB}$, o nível de $210 \mathrm{~g} \mathrm{~kg}^{-1}$ promoveu aumento do peso da gema aos 28 dias enquanto que o nível de $240 \mathrm{~g} \mathrm{~kg}^{-1}$ aumentou o peso do albúmen aos 35 dias de armazenamento. Foi observada tendência de acréscimo no peso de albúmen dos ovos até o período de armazenamento de 14 dias. Pode-se recomendar que rações para codornas japonesas na fase de produção sejam formuladas com balanço eletrolítico de $50 \mathrm{mEq} \mathrm{kg}{ }^{-1}$ de ração sem redução no desempenho produtivo e com $240 \mathrm{~g} \mathrm{~kg}^{-1}$ de proteína bruta, por aumentar o peso de albúmen de ovos armazenados por muito mais tempo, assim, mostrando ser uma alternativa para aumentar a vida útil do ovo.

Palavras-chave: Cloro, desempenho, potássio, qualidade dos ovos, sódio

\section{Introduction}

Quail farming has emerged as a prominent industry in the last decades, undergoing large adjustments to the domestic exploitation conditions. The increase in quail farming is a result of increasing egg consumption, advances in genetic breeding and nutrition, and low initial investment necessary for its establishment (CRUZ et al., 2009).

Among the studies on nutrition, few emphasize the importance of the right supply of minerals in poultry feeding, which are essential components to the birds' life as they participate in the formation of the skeleton and in the composition of their eggs' shell (BARRETO et al., 2007).

Possible changes in the quality of the egg and on the percentage of posture are also related to the age of birds (CHWALIBOG, 1992; CARNEIRO et al., 2014) and the use of alternative foods in the diet such as fish oil (SEIBEL; SOARES, 2004). Seibel and Soares (2004) emphasized the need to check variations in the moisture and ash content of albumin and yolk when using fish oil in the diet of quail.

The appropriate nutrition of the layer, including the minerals involved in the formation of shell, is one of the factors that should be carefully monitored in order to maintain its integrity. The main mineral to be considered in the feeding of layers is calcium (Ca), followed by phosphorus (P).The delicate electrolyte balance is important for the maintenance of homeostasis of these minerals (GONZALES, 1999).

Chlorine, sodium, and potassium, maintain the acid-base balance and interfere in bone growth, appetite, response to the thermal stress and the metabolism of some nutrients, thereby affecting the birds' performance in the starter and production phases (RODRIGUES et al., 2008).

Mongin (1968) was one of the first to discuss the importance of the cation-anion balance of birds' diet in the formation of the eggshell. The balance of these minerals (potassium, phosphorus, sodium, and chlorine) acts directly on the acidbase balance of birds and is involved in several physiological processes such as the maintenance of osmotic pressure within medium values, which may affect performance, calcium metabolism, and use of phosphorus (VIEITES et al., 2004; AHMAD; SARWAR, 2006).

Layers are affected by alterations in the acidbase balance during periods of high temperatures, which can trigger electrolyte and mineral imbalance that may result in small, thin-shelled eggs. Thus, during heat stress, there is an increase in the blood $\mathrm{pH}$ due to the loss of carbon dioxide, followed by a decrease in diffusible calcium, which in turn will lead to the production of eggs with a low shell quality (JUDICE et al., 2002). 
Eggshell quality is an economic issue that affects egg producers including increased production costs that can indirectly affect consumers. Because low eggshell quality is responsible for large egg losses, many nutritionists have sought to reduce these losses through the manipulation of dietary nutrients (JUDICE et al., 2002).

The use of salts to manipulate the dietary electrolyte balance is a feasible alternative to minimize the deleterious effect of heat stress. In practice, the most widely used salts are potassium chloride, sodium bicarbonate, and ammonium chloride (VIEITES et al., 2005). For layer birds, the recommended electrolyte balance levels for best productive performance and external eggshell quality are within the range from 174 to $205 \mathrm{mEq}$ $\mathrm{kg}^{-1}$ (MURAKAMI et al., 2003). However, few studies have confirmed the recommendations for these minerals.

Thus, this study was conducted to determine the electrolyte balance and crude protein levels that provide the best productive performance and eggshell quality in Japanese quail.

\section{Material and Methods}

The experiment was conducted in the Poultry Farming Section of the Center for Agricultural Sciences of Universidade Federal do Espírito Santo, Brazil. Six hundred 45-day-old female Japanese quails were used in the experiment spanning 84 days. The birds were distributed in a randomized block design, with a $5 \times 2$ factorial arrangement composed of five levels of electrolyte balance (50,

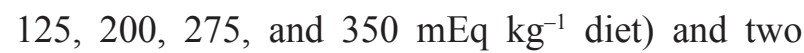
levels of crude protein (210 and $\left.240 \mathrm{~g} \mathrm{~kg}^{-1}\right)$. Each treatment contained five replicates with 12 birds per experimental unit.

Ground corn and soybean meal were used to formulate the diets (Table 1), according to NRC (1994) recommendations. The different levels of electrolyte balance for the diets with 210 and 240 $\mathrm{g} \mathrm{kg}^{-1}$ of crude protein (Table 2) were obtained by using a mixture of potassium carbonate ( $\mathrm{K}_{2} \mathrm{CO}_{3}$ ataconcentration of $56.52 \%$ ) and/or ammonium chloride $\left(\mathrm{NH}_{4}\right.$ Clat a concentration of $63.3 \%$ ), substituting the inert material. The crude protein levels were chosen based on NRC (1994) recommendations; however, they were elevated by 1 and $4 \%$, given that crude protein contributes to the acidification of the diet (VIEITES et al., 2004). Because loss of electrolytes occur via renal excretion, it is important to determine the interaction between crude protein and electrolyte balance. At higher acidity levels, caused by excess protein, there is increased excretion of electrolytes.

The electrolyte balance of the basal diets were chosen according to the Murakami et al. (2003) recommendation of $205 \mathrm{mEq} \mathrm{\textrm {kg } ^ { - 1 }}$ diet, varying by

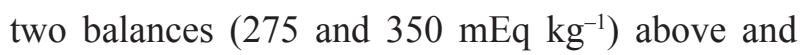

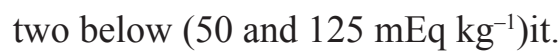

In the experiment, light (artificial + natural) was used for $17 \mathrm{~h}$, controlled by a timer. Temperature and humidity inside the shed were recorded twice daily using a maximum and minimum thermometer and dry and wet bulb thermometer. The average temperature observed in the shed during the trial period was of $22.5^{\circ} \mathrm{C}$, and relative humidity was $50.4 \%$.

The evaluated parameters were: feed intake $(\mathrm{g} /$ bird day ${ }^{-1}$ ), feed conversion to mass and dozen eggs ( $\mathrm{kg} \mathrm{kg}^{-1}$ and $\mathrm{kg} \mathrm{dz}^{-1}$ ), egg-laying rate (\%), average egg weight ( $\mathrm{g})$, egg mass $\left(\mathrm{g} / \mathrm{egg}\right.$ day $^{-1}$ ), final bird weight $(\mathrm{g})$, egg quality through albumin weight $(\mathrm{g})$, yolk weight $(\mathrm{g})$, and eggshell weight $(\mathrm{g})$.

To calculate the average egg weight, egg mass and feed conversion to mass and dozen, the eggs from the last four days of each experimental period were collected and used for the analysis of internal quality and shell. 
Table 1. Nutritional composition of the basal diets for laying Japanese quails ${ }^{1}$.

\begin{tabular}{|c|c|c|}
\hline \multirow{2}{*}{ Ingredients $\left(\mathrm{g} \mathrm{kg}^{-1}\right)$} & \multicolumn{2}{|c|}{ Crude protein level ( $\mathrm{g} \mathrm{kg}^{-1}$, as fed) } \\
\hline & 210 & 240 \\
\hline Corn & 562.300 & 505.570 \\
\hline Soybean meal & 262.350 & 270.310 \\
\hline Corn gluten, $60 \%$ & 58.500 & 98.970 \\
\hline Meat and bone meal, $45 \%$ & 15.840 & 35.870 \\
\hline Limestone & 53.090 & 51.640 \\
\hline Dicalcium phosphate & 9.220 & 3.680 \\
\hline Salt & 3.070 & 2.730 \\
\hline Soybean oil & 16.090 & 14.630 \\
\hline L-lysine $\mathrm{HCl}$ & 1.040 & 0.000 \\
\hline L-threonine & 1.090 & 0.090 \\
\hline DL-methionine & 1.000 & 0.000 \\
\hline Vitamin mix & 1.000 & 1.000 \\
\hline Mineral mix & 0.500 & 0.500 \\
\hline Choline chloride & 0.260 & 0.360 \\
\hline Antioxidant & 0.100 & 0.100 \\
\hline Coccidiostat & 0.050 & 0.050 \\
\hline Inert & 14.500 & 14.500 \\
\hline \multicolumn{3}{|c|}{ Calculated nutritional composition } \\
\hline Metabolizable energy, $\mathrm{kcal} \mathrm{kg}^{-1}$ & 2,900 & 2,900 \\
\hline Crude protein, $\mathrm{g} \mathrm{kg}^{-1}$ & 210 & 240 \\
\hline Calcium, $\mathrm{g} \mathrm{kg}^{-1}$ & 25 & 25 \\
\hline Available phosphorus, $\mathrm{g} \mathrm{kg}^{-1}$ & 3.50 & 3.50 \\
\hline Sodium, $\mathrm{g} \mathrm{kg}^{-1}$ & 1.50 & 1.50 \\
\hline Potassium, $\mathrm{g} \mathrm{kg}^{-1}$ & 6.56 & 6.73 \\
\hline Chlorine, $\mathrm{g} \mathrm{kg}^{-1}$ & 2.61 & 2.35 \\
\hline Digestible lysine, $\mathrm{g} \mathrm{kg}^{-1}$ & 9.50 & 9.50 \\
\hline Digestible met + cys, $\mathrm{g} \mathrm{kg}^{-1}$ & 7.20 & 7.20 \\
\hline Digestible threonine, $\mathrm{g} \mathrm{kg}^{-1}$ & 8.00 & 2.16 \\
\hline Digestible arginine, $\mathrm{g} \mathrm{kg}^{-1}$ & 11.94 & 13.29 \\
\hline Glycine + Serine, $\mathrm{g} \mathrm{kg}^{-1}$ & 19.39 & 23.05 \\
\hline Digestible tryptophan, $\mathrm{g} \mathrm{kg}^{-1}$ & 2.00 & 2.16 \\
\hline Digestible valine, $\mathrm{g} \mathrm{kg}^{-1}$ & 8.83 & 10.16 \\
\hline Electrolytic balance, $\mathrm{mEq} \mathrm{kg}{ }^{-1}$ & 159.70 & 171.30 \\
\hline
\end{tabular}

${ }^{1} \mathrm{NRC}$ (1994) recommendations.

Part of the eggs was chosen randomly and stored at room temperature for different durations $(0,7,14,21,28$, and 35 days). A semi-analytical balance was used to determine the weight of eggs and components (yolk, albumin, and shell). The effect of crude protein and electrolyte balance on dependent variables was analyzed within each time group, without taking into consideration the length of storage time as a factor studied.
Dead birds and left over feed were weighed in order to adjust the feed intake, weight gain in birds, egg-laying rate, and feed conversion according to the methodology described by Sakomura and Rostagno (2007). 
Table 2. Treatments with diets containing $210 \mathrm{~g} \mathrm{~kg}^{-1}$ and $240 \mathrm{~g} \mathrm{~kg}^{-1}$ crude protein.

\begin{tabular}{|c|c|c|c|c|c|}
\hline & \multicolumn{5}{|c|}{ Diets with $210 \mathrm{~g} \mathrm{~kg}^{-1}$ of crude protein } \\
\hline & \multicolumn{5}{|c|}{ Electrolytic balance $\left(\mathrm{mEq} \mathrm{Kg}{ }^{-1}\right)$} \\
\hline & 50 & 125 & 200 & 275 & 350 \\
\hline Basal diet & 98.50 & 98.50 & 98.50 & 98.50 & 98.50 \\
\hline $\mathrm{K}_{2} \mathrm{CO}_{3}$ & 0.614 & 0.194 & --- & --- & --- \\
\hline $\mathrm{NH}_{4} \mathrm{Cl}$ & 0.886 & 1.306 & 1.221 & 0.702 & 0.184 \\
\hline Inert & --- & --- & 0.279 & 0.798 & 1.317 \\
\hline \multirow[t]{4}{*}{ Total } & 100.0 & 100.0 & 100.0 & 100.0 & 100.0 \\
\hline & \multicolumn{5}{|c|}{ Diets with $240 \mathrm{~g} \mathrm{~kg}^{-1}$ of crude protein } \\
\hline & \multicolumn{5}{|c|}{ Electrolytic balance $\left(\mathrm{mEq} \mathrm{Kg}^{-1}\right)$} \\
\hline & 50 & 125 & 200 & 275 & 350 \\
\hline Basal diet & 98.50 & 98.50 & 98.50 & 98.50 & 98.50 \\
\hline $\mathrm{K}_{2} \mathrm{CO}_{3}$ & --- & --- & 0.199 & 0.717 & 1.236 \\
\hline $\mathrm{NH}_{4} \mathrm{Cl}$ & 0.679 & 0.259 & --- & --- & --- \\
\hline Inert & 0.821 & 1.241 & 1.302 & 0.783 & 0.264 \\
\hline Total & 100.0 & 100.0 & 100.0 & 100.0 & 100.0 \\
\hline
\end{tabular}

$\mathrm{K}_{2} \mathrm{CO}_{3}$ concentration of $56,52 \% ; \mathrm{NH}_{4} \mathrm{Cl}$ concentration of $63,3 \%$.

The collected data were checked for normal distribution of errors using the KolmogorovSmirnov test $(\mathrm{P}>0.05)$ and variance homogeneity by Bartlett's test $(\mathrm{P}>0.05)$. After considering these assumptions, the data were subjected to analysis of variance observing if the randomized block design with factorial arrangement, being the block the floor of the cage in which the experimental unit was. Variables were carefully examined, including the significance of isolated factors as well as the interactions among variables. For the electrolyte balance factor, the degrees of freedom were deployed in first and second-order polynomials. The criteria for validation in the models included $\mathrm{p}$-values, coefficient of determination $\left(\mathrm{r}^{2}\right)$, and $t$-test for the parameters of the equations. The StudentNewman-Keuls test $(\mathrm{P}<0.05)$ was used to verify the significance between the different electrolyte balance sheets. The response of the ANOVA is conclusive for the protein factor, as there were only two means. The statistical analysis and genetic software (UFV. SAEG, 2007) was used for these analyses.

\section{Results and Discussion}

No interaction effect was observed (Table 3) between the crude protein and electrolyte balance factors $(\mathrm{P}>0.05)$. When the factors were analyzed individually, no cause and effect relationship was observed, i.e., no regression effect of the electrolyte balance was observed ( $\mathrm{P}>0.05)$; also in addition, there was no significant effect of the crude protein levels on the performance variables $(\mathrm{P}>0.05)$. This was probably because the minimum protein level in the diet fulfilled the amino acids requirement for egg production in the quails.

The results obtained in this study are similar to the findings of Murakami et al. (2006), who found that when sodium chloride was included in the diet for laying Japanese quail, no significant differences were observed in the productive and egg-quality parameters at chlorine levels between 0.12 and $0.30 \%$. Ribeiro et al. (2008) investigated the sodium and chlorine requirements of laying Japanese quail (65 days old), with chlorine levels of $0.08,0.18$, 0.28 , and $0.38 \%$; they also did not observe any significant effect of the levels of these elements in the diets on feed intake. 
Table 3. Productive performance of Japanese quails fed diets containing different levels of crude protein and electrolytic balances.

\begin{tabular}{|c|c|c|c|c|c|c|c|c|}
\hline & \multicolumn{8}{|c|}{ Productive parameter } \\
\hline & $\begin{array}{c}\text { FI } \\
\left(\mathrm{g} / \text { bird day }^{-1}\right)\end{array}$ & $\begin{array}{l}\text { AFW } \\
(\mathrm{g})\end{array}$ & $\begin{array}{c}\text { WG } \\
\left(\mathrm{g} \mathrm{bird}^{-1}\right)\end{array}$ & $\begin{array}{c}\mathrm{FC} \\
\left(\mathrm{kg} \mathrm{kg}^{-1}\right)\end{array}$ & $\begin{array}{c}\mathrm{FC} \\
\left(\mathrm{kg} \mathrm{dozen}^{-1}\right)\end{array}$ & $\begin{array}{l}\text { ELR } \\
(\%)\end{array}$ & $\begin{array}{c}\text { AEW } \\
(\mathrm{g})\end{array}$ & $\begin{array}{c}\text { EM } \\
\left(\mathrm{g} /{\left.\text { bird } / \text { day }^{-1}\right)}\right.\end{array}$ \\
\hline \multicolumn{9}{|c|}{ Electrolytic balance $\left(\mathrm{mEq} \mathrm{kg}^{-1}\right)$} \\
\hline 50 & 25.45 & 174.78 & 14.48 & 2.431 & 0.354 & 87.89 & 11.94 & 10.50 \\
\hline 125 & 24.68 & 175.09 & 14.26 & 2.514 & 0.357 & 85.52 & 11.52 & 9.85 \\
\hline 200 & 24.19 & 174.05 & 12.93 & 2.358 & 0.332 & 88.42 & 11.70 & 10.33 \\
\hline 275 & 25.09 & 173.63 & 10.82 & 2.454 & 0.362 & 87.78 & 11.70 & 10.26 \\
\hline 350 & 25.22 & 171.63 & 11.73 & 2.539 & 0.359 & 85.83 & 11.59 & 9.95 \\
\hline \multicolumn{9}{|c|}{ Crude protein $(\%)$} \\
\hline 21 & 25.16 & 173.68 & 12.68 & 2.460 & 0.349 & 88.01 & 11.68 & 10.28 \\
\hline 24 & 24.70 & 173.99 & 13.00 & 2.458 & 0.357 & 86.17 & 11.71 & 10.08 \\
\hline $\begin{array}{l}\text { CV } \\
(\%)\end{array}$ & 5.70 & 2.56 & 4.89 & 7.87 & 10.60 & 7.66 & 3.13 & 7.08 \\
\hline $\mathrm{N}$ & 50 & 50 & 50 & 50 & 50 & 50 & 50 & 50 \\
\hline Mean & 24.82 & 173.74 & 13.06 & 2.59 & 0.361 & 83.62 & 11.62 & 9.70 \\
\hline STD & 1.61 & 5.46 & 5.35 & 0.28 & 0.04 & 8.72 & 0.49 & 1.00 \\
\hline \multirow[t]{2}{*}{ Effect* } & ns & $\mathrm{ns}$ & ns & ns & ns & $\mathrm{ns}$ & ns & ns \\
\hline & & \multicolumn{7}{|c|}{ Analysis of Variance $-\mathrm{P}$ Value } \\
\hline Bloco & 0.301 & 0.489 & 0.437 & 0.638 & 0.039 & 0.341 & 0.001 & 0.999 \\
\hline $\mathrm{PB}$ & 0.467 & 0.648 & 0.671 & 0.619 & 0.884 & 0.507 & 0.205 & 0.327 \\
\hline $\mathrm{BE}$ & 0.789 & 0.481 & 0.259 & 0.609 & 0.748 & 0.851 & 0.084 & 0.627 \\
\hline $\mathrm{PB}^{*} \mathrm{BE}$ & 0.313 & 0.079 & 0.417 & 0.732 & 0.457 & 0.199 & 0.138 & 0.359 \\
\hline
\end{tabular}

Effect": Polynomial analysis; CV (\%) = coefficient of variation; ns = not significant. FI- Feed intake; AFV- Average final weight; WG- Weight gain; FC- Feed conversion; ELR- Egg-laying rate; AEW- Average egg weight; EM- Egg mass.

Different results were presented by Moraes (2010), who observed a variation in the performance and quality of eggs from Japanese quails in the laying phase, when raised during winter and summer at electrolyte balance between 140 and $360 \mathrm{mEq} \mathrm{kg}{ }^{-1}$. Moraes demonstrated the importance of the electrolyte balance in the performance and egg quality of quails when subjected to low and high temperatures, which are different average temperature conditions from those of the present experiment.

The literature provides contradictory evidence regarding the levels of potassium and chlorine for quails in the laying phase. The reasons for this variation in the literature data may be the age of the evaluated birds as well as the management conditions and facilities.
There was no effect of electrolyte balance levels on feed conversion ( $\mathrm{P}>0.05)$, as observed by Raquel et al. (2010), when analyzing chlorine levels between 0.07 and $0.32 \%$ in diets for Italian quails (1 to 49 days). The effects of the electrolyte balance levels on feed conversion observed in the present study are consistent with those obtained by Vieites et al. (2005), who did not observe significant effects on the feed conversion of broilers ( 1 to 42 days)at electrolyte balance levels between 50 and $350 \mathrm{mEq}$ $\mathrm{kg}^{-1}$ in a diet with $20 \%$ crude protein.

In the present study, the average egg weight was not influenced by the protein level or by the dietary electrolyte balance. These results are not in agreement with those of Nobakht et al. (2007), wherein, the diet with $360 \mathrm{mEq} \mathrm{kg}{ }^{-1}$ was associated with the highest egg weight The absence of statistical difference for average egg weight in diets 
with different crude protein levels (21 and 24\%) can be explained by the similar amino acid content among the diets, especially digestible methionine + cystine, which is the main factor influencing egg weight, rather than the dietary crude protein level.

In this study, no significant effects on egg mass were observed in the different diets, which is explained by the absence of a statistical difference between the egg-laying rate and egg weight. The absence of a significant effect $(\mathrm{P}>0.05)$ for egg weight as well as egg mass may be related to the birds' age, because all birds were at the beginning of the production peak and consequently had greater uniformity in the production and quality of eggs during the experimental period.

The protein level of the diets did not affect $(\mathrm{P}>0.05)$ shell weight, and this finding was similar to that by Murakami et al.(1993). However, a significant effect $(\mathrm{P}<0.05)$ was observed on shell weight (Table 4) with the use of an electrolyte balance of 200
$\mathrm{mEq} \mathrm{kg}{ }^{-1}$ in the diet, for the eggs stored for seven days. This may be due to the increased proportion of sodium relative to chlorine in improving the resistance and thickness of the eggshell up to the electrolyte balance of $200 \mathrm{mEq} \mathrm{kg}{ }^{-1}$ in the diet. The levels of sodium, potassium, and chlorine, in each production cycle of the bird is of great importance, because these minerals are involved in many physiological processes, such an maintenance of osmotic pressure, electrolyte balance, and acid-base balance. The high concentration of anions in the diet (low $\mathrm{mEq}$ ) decreases the quality of eggshells and low $\mathrm{pH}$, while high concentration of cations (high $\mathrm{mEq}$ ) is associated with an improvement in the quality of eggshells and high $\mathrm{pH}$ in the blood (MILES; ROSSI, 1984). Adverse effects of excess chloride on the quality of egg shells are likely related to the effect of acidification on the uterine fluid chloride and its inhibitory action on carbonic anhydrase (YOSELEWITZ; BALNAVE, 1989).

Table 4. Effect of different electrolytic balances and crude protein levels on the average egg weight (EW) and shell weight (SW) of eggs from quails subjected to different storage times.

\begin{tabular}{|c|c|c|c|c|c|c|c|c|c|c|c|c|}
\hline & \multicolumn{12}{|c|}{ Days of storage } \\
\hline & \multicolumn{2}{|c|}{00} & \multicolumn{2}{|c|}{07} & \multicolumn{2}{|c|}{14} & \multicolumn{2}{|c|}{21} & \multicolumn{2}{|c|}{28} & \multicolumn{2}{|c|}{35} \\
\hline & EW & SW & EW & SW & EW & SW & EW & SW & EW & SW & EW & SW \\
\hline \multicolumn{13}{|c|}{ Electrolytic balance $\left(\mathrm{mEq} \mathrm{kg}^{-1}\right)$} \\
\hline 50 & 11.60 & 1.50 & 11.11 & $1.35 \mathrm{~b}$ & 10.92 & 1.24 & 10.79 & 1.30 & 10.58 & 1.35 & 10.25 & 1.23 \\
\hline 125 & 11.54 & 1.52 & 11.29 & $1.44 \mathrm{ab}$ & 11.14 & 1.27 & 10.74 & 1.38 & 10.55 & 1.34 & 10.64 & 1.36 \\
\hline 200 & 12.00 & 1.55 & 11.44 & $1.51 \mathrm{a}$ & 11.32 & 1.33 & 11.24 & 1.38 & 11.03 & 1.35 & 10.82 & 1.30 \\
\hline 275 & 11.67 & 1.55 & 11.49 & $1.41 \mathrm{ab}$ & 11.31 & 1.30 & 11.12 & 1.40 & 10.60 & 1.39 & 10.55 & 1.39 \\
\hline 350 & 11.60 & 1.55 & 10.32 & $1.38 \mathrm{~b}$ & 11.02 & 1.30 & 10.75 & 1.34 & 10.49 & 1.35 & 10.45 & 1.31 \\
\hline \multicolumn{13}{|c|}{ Crude protein $(\%)$} \\
\hline 21 & 11.69 & 1.54 & 11.34 & 1.41 & 11.11 & 1.30 & 10.89 & 1.34 & 10.75 & 1.38 & 10.56 & 1.32 \\
\hline 24 & 11.68 & 1.52 & 10.92 & 1.43 & 11.18 & 1.28 & 11.00 & 1.38 & 10.55 & 1.39 & 10.52 & 1.32 \\
\hline $\mathrm{CV} \%$ & 5.1 & 6.9 & 5.1 & 6.9 & 5.1 & 6.9 & 5.1 & 6.9 & 5.1 & 6.9 & 5.1 & 6.9 \\
\hline Effect* & $\mathrm{Ns}$ & ns & ns & ns & ns & ns & ns & ns & ns & ns & ns & ns \\
\hline
\end{tabular}

Effect*: Polynomial analysis; CV $(\%)=$ coefficient of variation; ns = not significant. 
The greater shell weight observed only at the 200 $\mathrm{mEq} \mathrm{kg}{ }^{-1}$ diet in eggs stored for seven days can also be explained based on the observations of Miles and Butcher (1998) in terms of the acid-base balance of hen diets. They report that no defined pattern in eggshell quality is likely in response to the $\mathrm{mEq}$ of the diet, and consequently, no effect on weight, since the other levels of $\mathrm{mEq} \mathrm{kg} \mathrm{kg}^{-1}$ in the diets and storage periods used in this study did not influence the eggshell quality.

According to Gonzales (1999), eggshell quality improves with an increase in sodium and potassium levels, but reduces with an increase in the chlorine level. In fact, the effects of these ions on the eggshell quality are not isolated, but they depend on their balance, as represented in Mongin equation (1980). However, according to Austic and Keshavarz (1984), the correlation between the dietary electrolyte balance (DEB) and eggshell thickness is low $(r=0.2)$.

According to Ribeiro et al. (2008), the increase in shell weight caused by the elevation in chlorine content in the diet occurs due to the acidification of the food bolus, which leads to an increased solubility and absorption of the minerals, such as phosphorus and calcium, essential for the formation of eggshell. In the present study, high and low levels of chlorine in the diet did not cause remarkable difference in shell weight, with the best results observed at the level of $200 \mathrm{mEq} \mathrm{kg}^{-1}$, providing evidence that the excess and deficiency of sodium, potassium, and chlorine promote electrolyte imbalance.

In this study, however, the high eggshell weight observed at the level of $200 \mathrm{mEq} \mathrm{kg^{-1 }}$ in the diet indicates the need for a balance among electrolytes, because excess or deficiency of these electrolytes may affect eggshell quality, making it thinner and prone to breakage, as observed by Keshavarz and Austic (1990). These researchers found that an increase in the acid load of diets for layers affected the quality of the egg shell, caused by increased calcium excretion.
Senkoylu et al. (2005) reported that an increase in DEB from 176 to $242 \mathrm{mEq} \mathrm{kg}{ }^{-1}$ does not improve the production or quality of eggs from layers. However, the electrolyte balance of $205 \mathrm{mEq} \mathrm{kg}{ }^{-1}$ for layers in the first production cycle and 174 $\mathrm{mEq} \mathrm{kg}^{-}$after forced molting have been effective in providing an optimal productive response and good eggshell quality (MURAKAMI et al., 2003). In addition, according to Reeve (1990), the use of an electrolyte balance above190 $\mathrm{mEq} \mathrm{\textrm {kg } ^ { - 1 }}$ in the diet would be sufficient for adequate eggshell quality.

The different electrolyte balance and protein levels used in this study did not influence the weight of eggs. The lowest and highest protein content in the diet was sufficient to meet the nutritional requirement for the production of eggs in Japanese quail.

Electrolyte balance levels did not alter egg white or yolk weight at the different storage periods, as observed by Bezerra et al. (2011), who evaluated different levels of chlorine $(0.07$ to $0.32 \%)$ in diets for laying Japanese quail. The protein levels influenced $(\mathrm{P}<0.05)$ the average weight of yolk and albumin in eggs (Table 5) obtained from quails fed 210 and $240 \mathrm{mEq} \mathrm{kg}{ }^{-1}$ protein at 28 and 35 days of storage, respectively, however, they did not change the weight of the eggs. The increased albumin weight found in the treatments with elevated protein content in the diets for quails may be related to its chemical composition, which consists of water and proteins such as albumin, transferrin, mucoid, mucin, lysozyme, avidin, and ovostatin. Comparing the values of the different days of storage with the average initial weight of albumin and yolk on the first day of storage, a trend towards an increase in yolk weight and decrease in albumin weight were observed as the number of storage days advanced; this was likely due to the water movement from the egg white to the yolk, as observed by Griswold (1972). 
Table 5. Effect of different electrolytic balances and crude protein levels on the average weight of yolk (YW) and albumen (AW) of quail eggs subjected to different storage times.

\begin{tabular}{|c|c|c|c|c|c|c|c|c|c|c|c|c|}
\hline & \multicolumn{12}{|c|}{ Days of storage } \\
\hline & \multicolumn{2}{|c|}{00} & \multicolumn{2}{|c|}{07} & \multicolumn{2}{|c|}{14} & \multicolumn{2}{|c|}{21} & \multicolumn{2}{|c|}{28} & \multicolumn{2}{|c|}{35} \\
\hline & YW & AW & YW & AW & YW & AW & YW & AW & YW & AW & YW & AW \\
\hline \multicolumn{13}{|c|}{ Electrolytic balance $\left(\mathrm{mEq} \mathrm{kg}{ }^{-1}\right)$} \\
\hline 50 & 3.7 & 3.5 & 3.7 & 4.8 & 3.8 & 4.8 & 4.1 & 4.3 & 4.2 & 4.0 & 4.5 & 3.6 \\
\hline 125 & 3.6 & 3.4 & 3.9 & 4.9 & 4.0 & 5.0 & 4.2 & 4.2 & 4.2 & 3.9 & 4.5 & 3.9 \\
\hline 200 & 3.8 & 3.6 & 3.8 & 5.1 & 3.9 & 5.0 & 4.2 & 4.4 & 4.2 & 4.3 & 4.2 & 4.0 \\
\hline 275 & 3.7 & 3.6 & 3.8 & 5.2 & 3.8 & 5.3 & 4.3 & 4.5 & 4.5 & 4.0 & 4.7 & 3.7 \\
\hline 350 & 3.7 & 3.5 & 3.6 & 5.1 & 3.9 & 4.7 & 4.9 & 4.5 & 4.3 & 3.6 & 4.5 & 3.8 \\
\hline \multicolumn{13}{|c|}{ Crude protein $(\%)$} \\
\hline 21 & 3.7 & 3.5 & 3.7 & 5.1 & 4.0 & 4.9 & 4.1 & 4.4 & $4.4^{\mathrm{a}}$ & 3.9 & 4.6 & $3.7^{\mathrm{b}}$ \\
\hline 24 & 3.7 & 3.5 & 3.8 & 5.0 & 3.8 & 5.0 & 4.2 & 4.4 & $4.1^{\mathrm{b}}$ & 4.0 & 4.4 & $3.9^{\mathrm{a}}$ \\
\hline CV\% & 6.6 & 7.6 & 6.6 & 7.6 & 6.6 & 7.6 & 6.6 & 7.6 & 6.6 & 7.6 & 6.6 & 7.6 \\
\hline Effect* & ns & $\mathrm{ns}$ & ns & ns & $\mathrm{ns}$ & $\mathrm{ns}$ & $\mathrm{ns}$ & ns & ns & $\mathrm{ns}$ & ns & ns \\
\hline
\end{tabular}

Effect ${ }^{*}$ : Polynomial analysis; CV $(\%)=$ coefficient of variation; $\mathrm{ns}=$ not significant.

Albumin weight is an excellent indicator of the quality of eggs. In this study, a trend in different storage periods was observed, with the best albumin weight found in eggs stored for 14 days. The length of storage period was not taken into consideration in this study, and factor of the analysis have been carried out individually to the crude protein factors and electrolyte balance within each storage time.

\section{Conclusions}

Taking into consideration that the electrolyte balance levels did not indicate deficiency or excess that could be determined by alterations in the quails' performance, a diet with level of $50 \mathrm{mEq} \mathrm{kg}{ }^{-1}$ can be recommended for laying Japanese quails. A tendency toward increased albumin weight in eggs stored for a period of 14 days was observed. A diet for laying Japanese quail with a high protein content (24\%) increased the albumin weight of eggs stored for a longer duration, thus demonstrating an alternative means to increasing the shelf life of eggs.

\section{References}

AHMAD, T.; SARWAR, M. Dietary electrolyte balance: implications in heat stressed broilers. World's Poultry Science Association, Cambridge, v. 62, n. 4, p. 638-653, 2006.

AUSTIC, R. E.; KESHAVARZ, K. Dietary electrolytes and egg shell quality. In: CORNELL NUTRITION CONFERENCE FOR FEED MANUFACTURES, 1., 1984, Syracuse. Proceedings... Syracuse: University of Cornell, 1984. p. 63-69.

BARRETO, S. L. T.; PEREIRA, C. A.; UMIGI, R. T.; ROCHA, T. C.; ARAÚJO, M. S.; SILVA, C. S.; FILHO, R. A. T. Determinação da exigência nutricional de cálcio de codornas japonesas na fase inicial do ciclo de produção. Revista Brasileira de Zootecnia, Viçosa, MG, v. 36, n. 1, p. 68-78, 2007.

BEZERRA, R. M.; FREITAS, E. R.; BRAZ, N. M.; XAVIER, R. P. S.; FARIAS, N. N. P.; SÁ, N. L. Níveis de cloro para codornas japonesas na fase de postura. Revista Brasileira de Zootecnia, Viçosa, MG, v. 40, n. 11, p. 2394-2399, 2011.

CARNEIRO, T. C.; SANTOS, T. C.; MURAKAMI, A. E.; ROSSI, R. M.; FANHANI, J. C.; STEFANELLO, C. Influência da idade dos reprodutores de codornas de postura na reprodução, na qualidade de ovos e na morfologia dos órgãos genitais. Semina: Ciências Agrárias, Londrina, v. 35, n. 5, p. 2449-2466, 2014.

CHWALIBOG, A. Factorial estimation of energy requeriment for egg production. Poultry Science, Champaign, v. 71, n. 3, p. 509-515, 1992. 
CRUZ, V. C.; FERNANDEZ, I. B.; TRAVA, C. M.; SEDANO, A. A.; PICCININ, A.; MAIOLI, M. A. Suplementação dietética com selênio e zinco orgânicos na qualidade interna e externa de ovos de codornas japonesas submetidas a estresse térmico. In: REUNIÃO ANUAL DA SOCIEDADE BRASILEIRA DE ZOOTECNIA, 46., 2009, Maringá. Anais... Maringá: Universidade Estadual de Maringá, 2009. p. 1-3.

GONZALES, E. A. A qualidade da casca do ovo. Revista Alimentação Animal, São Paulo, v. 4, n. 16, p. 20-22, 1999. Disponível em: <sindiracoes.org.br/wp-content/ uploads/2015/03/revista_ano4_n16.pdf $>$. Acesso em: 26 jun. 2015.

GRISWOLD, R. M. Estudo experimental dos alimentos. Rio de Janeiro: E. BLÜCHER, 1972. 469 p.

JUDICE, J. P. M.; BERTECHINI, A. G.; MUNIZ, J. A. RODRIGUES, P. B.; FASSANI, E. J. Balanço cátioaniônico das rações e manejo alimentar para poedeiras de segundo ciclo. Ciência Agrotécnica, Lavras, v. 26, n. 3, p. 598-609, 2002.

KESHAVARZ, K.; AUSTIC, R. E. Effect of dietary minerals onacid-base balance and eggshell quality in chickens. Journal of Nutrition, Syracuse, v. 120, n. 11, p. 1360-1369, 1990.

MILES, R. D.; BUTCHER, G. D. Cationes \& aniones. Poultry Industry, Rockford, v. 45, n. 1, p. 50-51, 1998.

MILES, R. D.; ROSSI, A. Cation-anion balance in laying hens. In: FLORIDA NUTRITIONAL CONFERENCE, 1984, Clearwater Beach. Proceedings... Clearwater Beach: University of Florida, 1984. p. 15-22.

MONGIN, P. Electrolytes in nutrition: a review of basic principles and practical application in poultry and swine. In: ANNUAL MINNESOTA CONFERENCE, 3., 1980, Illinois. Proceedings... Illinois: Institute Minnesota Center, 1980. p. 1-15.

Role of acid-base balance in the physiology of egg shell formation. World's Poultry Science Journal, Cambridge, v. 24, n. 3, p. 200-230, 1968.

MORAES, M. T. T. Balanço eletrolitico para codornas japonesas (coturnix coturnix japonica) na fase de produção. 2010. Dissertação (Mestrado em Nutrição e Alimentação Animal) - Curso de Pós-Graduação em Ciências Veterinárias. Universidade Federal do Paraná, Curitiba.

MURAKAMI, A. E.; FIGUEIREDO, D. F.; PERUZZI, A. Z.; FRANCO, J. R. G. F.; SAKAMOTO, M. I. Níveis de sódio para poedeiras comerciais no primeiro e segundo ciclos de produção. Revista Brasileira de Zootecnia, Viçosa, MG, v. 32, n. 6, p. 1674-1680, 2003.
MURAKAMI, A. E.; MORAES, V. M. B.; ARIKI, J.; JUNQUEIRA, O. M.; KRONCA, S. N. Níveis de proteína e energia em rações para codornas japonesas (Coturnix japonica) em postura. Revista Brasileira de Zootecnia, Viçosa, MG, v. 22, n. 4, p. 541-551, 1993.

MURAKAMI, A. E.; SAKAMOTO, M. I. L.; SOUZA, M. G.; FRANCO, J. R. G.; MITUO, M. A. O. Determinação do melhor nível de sal comum para codornas japonesas em postura. Revista Brasileira de Zootecnia, Viçosa, MG, v. 35, n. 6, p. 2333-2337, 2006.

NOBAKHT, A.; SHIVAZAD, M.; CHAMANY, M.; SAFAMEHER, A. R. The effects of dietary electrolyte balance on the performance and eggshell quality in the early laying period. Journal of Animal and Veterinary Advances, Faisalabad, v. 6, n. 8, p. 991-995, 2007.

NATIONAL RESEARCH COUNCIL - NRC. Nutrient requirements of poultry. $9^{\text {th }}$ rev. Washington: National Academy Press, 1994.

RAQUEL, D. L.; LIMA, R. C.; FREITAS, E. R.; SÁ, N. L.; XAVIER, R. P. S.; PAIVA, A. C. Níveis de cloro para codornas italianas destinadas à produção de carne. Acta Scientiarum. Animal Sciences, Maringá, v. 32, n. 1, p. 39-45, 2010.

REEVE, A. The role of sodium bicarbonate in improving eggshell quality. Management guide. Lyon: Institut de Selection Animale, 1990.7 p. (Technical Note, 19).

RIBEIRO, M. L. G.; VILAR DA SILVA, J. H.; ARAÚJO, J. A.; RODRIGUES, P. B.; COSTA, F. G. P.; JORDÃO FILHO, J. Níveis de sódio na ração de frangas de 7 a 12 semanas de idade. Ciência Agrotécnica, Lavras, MG, v. 32, n. 4, p. 1304-1310, 2008.

RODRIGUES, V. P.; COSTA, F. G. P.; GOULART, C. C.; LIMA, M. R.; SILVA, J. H. V.; SANTOS, C. S. Exigência de cloro para codornas japonesas de 1 a 21 dias de idade. In: CONGRESSO BRASILEIRO DE ZOOTECNIA, ZOOTEC, 2008, João Pessoa. Anais... João Pessoa: Gmosis, 2008. CD-ROM.

SAKOMURA, N. K.; ROSTAGNO, H. S. Métodos de pesquisa em nutrição de monogástricos. Jaboticabal: FUNEP, 2007. 283 p.

SEIBEL, N. F.; SOARES, L. A. S. Efeito do resíduo de pescado sobre as características físicas e químicas de ovos de codornas armazenados em diferentes períodos. Semina: Ciências Agrárias, Londrina, v. 25, n. 1, p. 3544, 2004.

SENKOYLU, N.; AKYUREK, H.; ERSIN SAMLI, H.; AGMA, A. Assessment the impacts of dietary electrolyte balance levels on laying performance of commercial White layers. Pakistan Journal of Nutrition, Faisalabad, v. 4, n. 6, p. 423-427, 2005. 
UNIVERSIDADE FEDERAL DE VIÇOSA - UFV. SAEG - Sistema de análises estatísticas e genéticas SAEG. Versão 8. 0. Viçosa, MG: UFV, 2007. 142 p.

VIEITES, F. M.; MORAES, G. H. K.; ALBINO, L. F.; ROSTAGNO, H. S.; RODRIGUES, A. C.; SILVA, F. A.; TEJEDOR, A. A. Balanço eletrolítico e níveis de proteína bruta sobre o parâmetros sanguíneos e ósseos de frangos de corte aos 21 dias de idade. Revista Brasileira de Zootecnia, Viçosa, MG, v. 33, n. 6, p. 1520-1530, 2004.
VIEITES, F. M.; MORAES, G. H. K.; ALBINO, L. F.; ROSTAGNO, H. S.; TEJEDOR, A. A.; VARGAS JUNIOR, J. G. Balanço eletrolítico e níveis de proteína bruta sobre o desempenho, rendimento de carcaça e umidade da cama de frangos de corte de 1 a 42 dias de idade. Revista Brasileira de Zootecnia, Viçosa, MG, v. 34, n. 6, p. 1990-1999, 2005.

YOSELEWITZ, A.; BALNAVE, D. The influence of saline drink ink water on the activity in the shell gland of laying hens. Australian Journal Agricultural Researches, Melbourne, v. 40, n. 5, p. 1111-1115, 1989. 
